American Journal of Agricultural and Biological Sciences 6 (1): 172-179, 2011

ISSN 1557-4989

(C) 2010 Science Publications

\title{
Corn (Zea Mays L.) Plant Characteristics and Grain Yield Response to N Fertilization Programs in No-Tillage System
}

\author{
Kesi Liu and Pawel Wiatrak \\ Department of Entomology, Soils and Plant Sciences, Clemson University, \\ Edisto Research and Education Center, Blackville, SC 29817
}

\begin{abstract}
Problem statement: Nitrogen application timing and Nitrogen $(\mathrm{N})$ rate are two important factors to influence corn production in No-Tillage (NT) system, but N recommendations may need to be revised due to insufficient rainfall in dryland rain-fed environment. Approach: This study was to determine the effects of two $\mathrm{N}$ application timing (planting and split application at planting and V6 corn growth stage) and five $\mathrm{N}$ rates $\left(0,45,90,135\right.$ and $\left.180 \mathrm{~kg} \mathrm{~N} \mathrm{ha}^{-1}\right)$ on corn plant characteristics and grain yield under rain-fed and low corn yield environment. Plant characteristics included the measurement of plant height, ear height, relative chlorophyll content (SPAD) and normalized Difference Vegetation Index (NDVI). Results: Plant height and ear height at R1 stage, SPAD at R1 and NDVI at V8 and R1 increased significantly with increasing $\mathrm{N}$ rates, while $\mathrm{N}$ application timing had no effect on measured canopy characteristics. Grain yield increased from 2.2-3.8 $\mathrm{Mg} \mathrm{ha}^{-1}$ as N rate changed from $0-180 \mathrm{~kg} \mathrm{ha}^{-1}$. However, applying more than $90 \mathrm{~kg} \mathrm{~N} \mathrm{ha}^{-1}$ did not significantly increase grain yields. The $\mathrm{N}$ application timing did not influence yield. Strong correlations were observed among corn plant characteristics and between plant NDVI at V8 and R1 stages and grain yields. Conclusion: These results indicate that $\mathrm{N}$ application timing was not important factor to affect corn plant characteristics and grain yield under rain-fed and low corn yield dryland conditions and we may not expect a significant grain yield increase with application exceeding $90 \mathrm{~kg} \mathrm{~N} \mathrm{ha}^{-1}$ under these conditions. Plant NDVI at V8 and R1 stage could be a good indicator to predict corn grain yield.
\end{abstract}

Key words: No-Tillage system (NT), Soil Plant Analysis Development (SPAD), chlorophyll meter, Normalized Difference Vegetation Index (NDVI), grain yield, chlorophyll content, Conventional Tillage (CT), Leaf Area Index (LAI)

\section{INTRODUCTION}

Fawcett and Towery (2002) reported that the area of No-Tillage system (NT) in field crop systems has increased from 6.8-22.4 million ha from 1990-2002 in the United States. Compared to Conventional Tillage (CT), no-tillage has been shown to significantly reduce soil erosion and nutrient leaching and run off (Raczkowski et al., 2009), increase soil water storage and soil organic matter (Fabrizzi et al., 2005; Spargo et al., 2008)(.. In Watkinsville, Georgia, Endale et al. (2008) reported that NT increased corn grain yield by $11 \%$ and soil water content by $18 \%$ compared with CT during a 5 year study.

Nitrogen $(\mathrm{N})$ is the most important and limited nutrient in corn production. Numerous studies have reported positive effects of $\mathrm{N}$ fertilization on corn plant biomass, photosynthesis and grain yield (Fabrizzi et al., 2005; Ma et al., 2005; Uribelarrea et al., 2009).
Nitrogen fertilizer rate and application timing are two important factors affecting $\mathrm{N}$ use efficiency. Therefore, a better understanding of corn yield response to $\mathrm{N}$ fertilizer application is important in providing effective $\mathrm{N}$ management recommendations and minimizing the potential detrimental effect on environment.

Precision agriculture technologies are becoming an integral part of farming operations for crop production and fertilizer management. These technologies, especially optical sensing, can help estimate plant nutrient status. Normalized Difference Vegetative Index (NDVI) and chlorophyll (SPAD) measurements are commonly used spectral indices in field practices due to their effectiveness and ease of use. Plant NDVI relates the reflectance in the red (Red NDVI) and Near Infrared (NIR) spectral light bands. The absorption in the red band estimates the chlorophyll content and NIR band is sensitive to canopy cover (Shanahan et al., 2001). Many researchers have reported a good relationship between plant NDVI and photosynthetic

Corresponding Author: Pawel Wiatrak, Department of Entomology, Soils and Plant Sciences, Clemson University, Edisto Research and Education Center, Blackville, SC 29817

Tel: 803-284-3343 ext. 261 Fax: 803-284-3684 
efficiency (Freeman et al., 2007; Inman et al., 2007), , plant N status (Rui et al., 2009; Rambo et al., 2010) and corn yield (Martin et al., 2005; Inman et al., 2008). SPAD measures relative chlorophyll content in plant leaves. Because chlorophyll content is closely related to $\mathrm{N}$ supply (Pandey et al., 2000), SPAD is also used to diagnose corn $\mathrm{N}$ status and predict corn grain yield potential (Bullock and Anderson, 1998; Vetsch and Randall, 2004). However, very little published results exist on using optical sensing technology for NT dryland corn in low-yield dryland environment in the southeastern US. Therefore, the main objectives of this study were to (1) quantify the effects of $\mathrm{N}$ fertilization rate and method on corn canopy characteristics and grain yields in a NT system and (2) estimate the relationship between optical plant vegetation indices and corn growth and grain yields.

\section{MATERIALS AND METHODS}

Experimental site: The field research was conducted at Clemson University's Edisto Research and Education Center near Blackville, SC $\left(33^{\circ} 21^{\prime} \mathrm{N}, 81^{\circ} 19^{\prime} \mathrm{W}\right)$ under dryland conditions from 2007 to 2009. Soil was classified as Dothan loamy sand (fine loamy, kaolinitic, thermic Plinthic Kandiudult) with average soil $\mathrm{pH}$ of 6.2. Mehlich I extractable $\mathrm{P}, \mathrm{K}, \mathrm{Mg}$ and $\mathrm{Ca}$ concentrations in soil at the beginning of the study were 29, 59, 88 and $325 \mathrm{mg} \mathrm{kg}^{-1}$, respectively. Organic matter in the top $15 \mathrm{~cm}$ layer was $16 \mathrm{mg} \mathrm{kg}^{-1}$. There was no irrigation system utilized in this study. Monthly precipitation and average temperature during experimental period are shown in Table 1.

Treatments design and management: The study was a split-plot design in a randomized complete block design with four replications. Two $\mathrm{N}$ application methods (single $\mathrm{N}$ application and split $\mathrm{N}$ application) were main plots and five $\mathrm{N}$ rates $(0,45,90,135$ and $180 \mathrm{~kg} \mathrm{~N} \mathrm{ha}{ }^{-1}$ ) were sub-plots. With single $\mathrm{N}$ application, all $\mathrm{N}$ was applied at planting. Split $\mathrm{N}$ application consisted of applying $35 \mathrm{~kg} \mathrm{~N} \mathrm{ha}^{-1}$ at planting (excluding plots without $\mathrm{N}$ application) and the rest of $\mathrm{N}$ was applied to corn in selected plots at V6 growth stage. These two $\mathrm{N}$ application methods represented $\mathrm{N}$ application timing. The $\mathrm{N}$ source was the liquid form of urea-ammonium sulfate (25-0-0-3.5 of $\mathrm{N}-\mathrm{P}_{2} \mathrm{O}_{5}-\mathrm{K}_{2} \mathrm{O}-\mathrm{S}$ ), which was applied to corn using a Reddick 4-row fertilizer applicator (Reddick Equip. Co., Inc., Williamson, NC). Each plot was 3.9 m wide by $6.1 \mathrm{~m}$ long.

Winter wheat (Triticum aestivum L.), was planted as a cover crop over the entire study area on 8 December 2006, 21 November 2007 and 26 November 2008 and killed by spraying glyphosate at a rate of 1.1 $\mathrm{kg}$ a.i. ha $\mathrm{h}^{-1}$ on 26 February 2007, 6 March in 2008 and 2009. Pioneer $31 \mathrm{G} 65$ corn (Pioneer Hi-Bred International Inc., Johnston, IA) was planted at 69,200 seeds $\mathrm{ha}^{-1}$ and $0.97 \mathrm{~m}$ row spacing using a John Deere 7300 MaxEmerge II vacuum planter (John Deere Co., Moline, IL) on 14, 18 and 23 March in 2007, 2008 and 2009, respectively. During corn growing season, weed control was based on the South Carolina Extension recommendations.

Plant measurements: Plant height, ear height, NDVI, SPAD and corn grain yield were recorded to evaluate their responses to $\mathrm{N}$ fertilization management strategies. Plant height, ear height, canopy light reflectance (Normalized Difference Vegetation Index (NDVI)) and leaf relative chlorophyll content (SPAD) were used to evaluate plant canopy characteristics. Corn growth, between V6 and R1 stages, was reported as an important period due to a strong relationship between plant characteristics and corn grain yield (Raun et al., 2005; Teal et al., 2006). In our study, corn V8 and R1 stages were selected to evaluate plant characteristics. Plant height and ear height were measured from the ground to the tip of the tassel and base of the corn ear, respectively at R1 stage. Plant chlorophyll (SPAD) and NDVI were determined at V8 and R1 stages.

Table 1: Average monthly air temperature and total precipitation during corn growing season at Edisto REC, Blackville, SC, 2007-2009

\begin{tabular}{|c|c|c|c|c|c|c|}
\hline \multirow[b]{2}{*}{ Year } & \multicolumn{6}{|l|}{ Month } \\
\hline & March & April & May & June & July & August \\
\hline \multicolumn{7}{|l|}{ Temperature $\left({ }^{\circ} \mathrm{C}\right)$} \\
\hline 2007 & 14.7 & 16.5 & 20.9 & 24.6 & 25.1 & 27.2 \\
\hline 2008 & 13 & 16.5 & 21 & 26.4 & 25.6 & 25.2 \\
\hline 2009 & 12.8 & 16.8 & 21.4 & 25.9 & 25.3 & 25.7 \\
\hline 20-yr. Average & 16.4 & 17.6 & 21.7 & 25.2 & 26.7 & 25.9 \\
\hline \multicolumn{7}{|c|}{ Precipitation (mm) } \\
\hline 2007 & 49 & 99 & 14 & 151 & 113 & 70 \\
\hline 2008 & 72 & 63 & 76 & 44 & 146 & 161 \\
\hline 2009 & 85 & 137 & 284 & 54 & 147 & 24 \\
\hline 20 year Average & 106 & 80 & 88 & 129 & 130 & 123 \\
\hline
\end{tabular}


Plant measurements (plant and ear height and chlorophyll) were conducted based on 10 randomly selected plants from each plot. Plant NDVI was measured at the center of each plot at V8 and R1 stages using the GreenSeeker ${ }^{\mathrm{TM}}$ hand held optical sensing instrument (NTech Industries, Inc. Ukiah, CA). Relative chlorophyll (SPAD) content was measured in corn leaves with Minolta SPAD-520 meter (Konica Minolta Sensing, Inc., Japan) at the V8 and R1 stages. At least ten SPAD meter readings were collected either in the upper most fully expanded corn leaves (V8 stage) or ear leaves (R1 stage) from each plot and the average value was recorded. Corn grain was harvested from the entire length of two center rows by hand on 29 and 30 August in 2007 and using an Almaco plot combine (Almaco, Nevada, IA) on 22 and 18 August in 2008 and 2009, respectively. Grain moisture was measured using the Burrows Model MC750 Digital Moisture Computer (Seedburo Equip. Co., Chicago, IL) and grain yield was adjusted to $155 \mathrm{~g} \mathrm{~kg}^{-1}$ moisture content.

Statistical analysis: The effects of $\mathrm{N}$ application timing and $\mathrm{N}$ rate on corn plant height, ear height, NDVI, SPAD and grain yield were assessed using the PROC MIXED procedure of SAS (Littell et al., 2006). Year, $\mathrm{N}$ application timing, $\mathrm{N}$ rate and their interactions were considered fixed effects. Replication (block) and its interactions with treatments were considered random effects. Year was considered a fixed effect because treatments were imposed on the same experimental unit each year, so there may have been cumulative effects over time. Data were analyzed by year when the interaction with year was significant. Single degree-offreedom contrasts were used to compare years and fertilization timing methods. The relationships between corn grain yield and plant height, cob-height, NDVI and SPAD were evaluated using the PROC REG procedure in SAS (Freund and Littell, 2000). The correlations were accessed using Pearson's correlation coefficients generated by the PROC CORR statement of SAS (SAS institute, Inc., 2000). Treatment effects and interactions were considered significant if $\mathrm{p} \leq 0.05$.

\section{RESULTS}

Plant characteristics: Plant height and ear height were mainly affected by $\mathrm{N}$ rate. Averaged across the 3 year, plant height and ear height significantly increased with increasing $\mathrm{N}$ rate (Fig. 1). The $\mathrm{N}$ application significantly increased plant height (from 12-21 cm) compared to treatment without $\mathrm{N}$ application (Fig. 1). However, increasing rates above $45 \mathrm{~kg} \mathrm{ha}^{-1}$ did not significantly increase plant height. Ear height increased from 52-66 $\mathrm{cm}$ as $\mathrm{N}$ rate increased from $0-180 \mathrm{~kg} \mathrm{~N} \mathrm{ha}^{-1}$. Ear height was $13-27 \%$ greater under $\mathrm{N}$ fertilization compared with $0 \mathrm{~kg} \mathrm{~N}$ application and greatest ear height was recorded at 135 and $180 \mathrm{~kg} \mathrm{~N} \mathrm{ha}^{-1}$.

Increasing $\mathrm{N}$ fertilization increased relative chlorophyll (SPAD) content at R1, but not at V8 growth stage (Fig. 1). SPAD ranged from 41-42 at V8 stage and from 33-42 at R1 stage as $\mathrm{N}$ rate increased from 0 $180 \mathrm{~kg} \mathrm{~N} \mathrm{ha}{ }^{-1}$. There was no significant difference in SPAD readings at $\mathrm{R} 1$ stage with $\mathrm{N}$ rate increase above $90 \mathrm{~kg} \mathrm{~N} \mathrm{ha}{ }^{-1}$. Plant NDVI increased from 0.54-0.66 at V8 growth stage and from $0.49-0.58$ at R1 stage as $\mathrm{N}$ rate increased from $0-180 \mathrm{~kg} \mathrm{~N}^{-1}$ (Fig. 1). Compared to a treatment without $\mathrm{N}$ application, significantly higher NDVI was observed with $\mathrm{N}$ applications at V8 and $135 \mathrm{~kg} \mathrm{~N} \mathrm{ha}^{-1}$ at $\mathrm{R} 1$ stage. However, no significant increase in plant NDVI was observed with $\mathrm{N}$ rates higher than 45 and $90 \mathrm{~kg} \mathrm{~N}^{-1}$ at V8 and R1 stage, respectively. At $\mathrm{R} 1$ growth stage, the $180 \mathrm{~kg} \mathrm{~N} \mathrm{ha}^{-1}$ treatment had the highest NDVI value, which was significantly greater compared to treatments with 0 and $45 \mathrm{~kg} \mathrm{~N} \mathrm{ha}^{-1}$.

Corn grain yield: The $\mathrm{N}$ fertilization method $\mathrm{x} \mathrm{N}$ rate interaction was not significant, but there was a significant influence of year and $\mathrm{N}$ rate on yields. Corn grain yield significantly decreased from $4.7 \mathrm{Mg} \mathrm{ha}^{-1}$ in 2007-2.3 $\mathrm{Mg} \mathrm{ha}^{-1}$ in 2008 and $2.4 \mathrm{Mg} \mathrm{ha}^{-1}$ in 2009. Increasing $\mathrm{N}$ rate increased corn grain yields (Fig. 2). Grain yields increased 32, 59, 55 and $73 \%$ with $N$ rates of $45,90,135$ and $180 \mathrm{~kg} \mathrm{~N} \mathrm{ha}{ }^{-1}$, respectively, compared to treatment without $\mathrm{N}$ application. However, rates greater than $90 \mathrm{~kg} \mathrm{~N} \mathrm{ha}{ }^{-1}$ did not significantly improve grain yields.

Correlation among variables: Corn grain yield was significantly correlated with ear height at R1 stage and NDVI at V8 and R1 stages; however, there was no significant correlation between grain yields and plant height at R1 and SPAD at V8 and R1 corn stages (Table 2). The regression analyses of ear height at R1 and NDVI at V8 and R1 explained 8, 12 and $6 \%$ of grain yield variability, respectively. Plant height had a strong positive relationship with ear height, SPAD and NDVI at R1 stage with $\mathrm{r}^{2}$ of 0.84 , 0.32 and 0.61 , respectively (Fig. 3). Ear height was positively correlated with SPAD and NDVI at R1 growth stage (Table 2 and Fig. 4). Plant NDVI increased linearly with increasing SPAD (Fig. 5). The linear regression equations at these two stages were similar. 
Am. J. Agri. \& Biol. Sci., 6 (1): 172-179, 2011
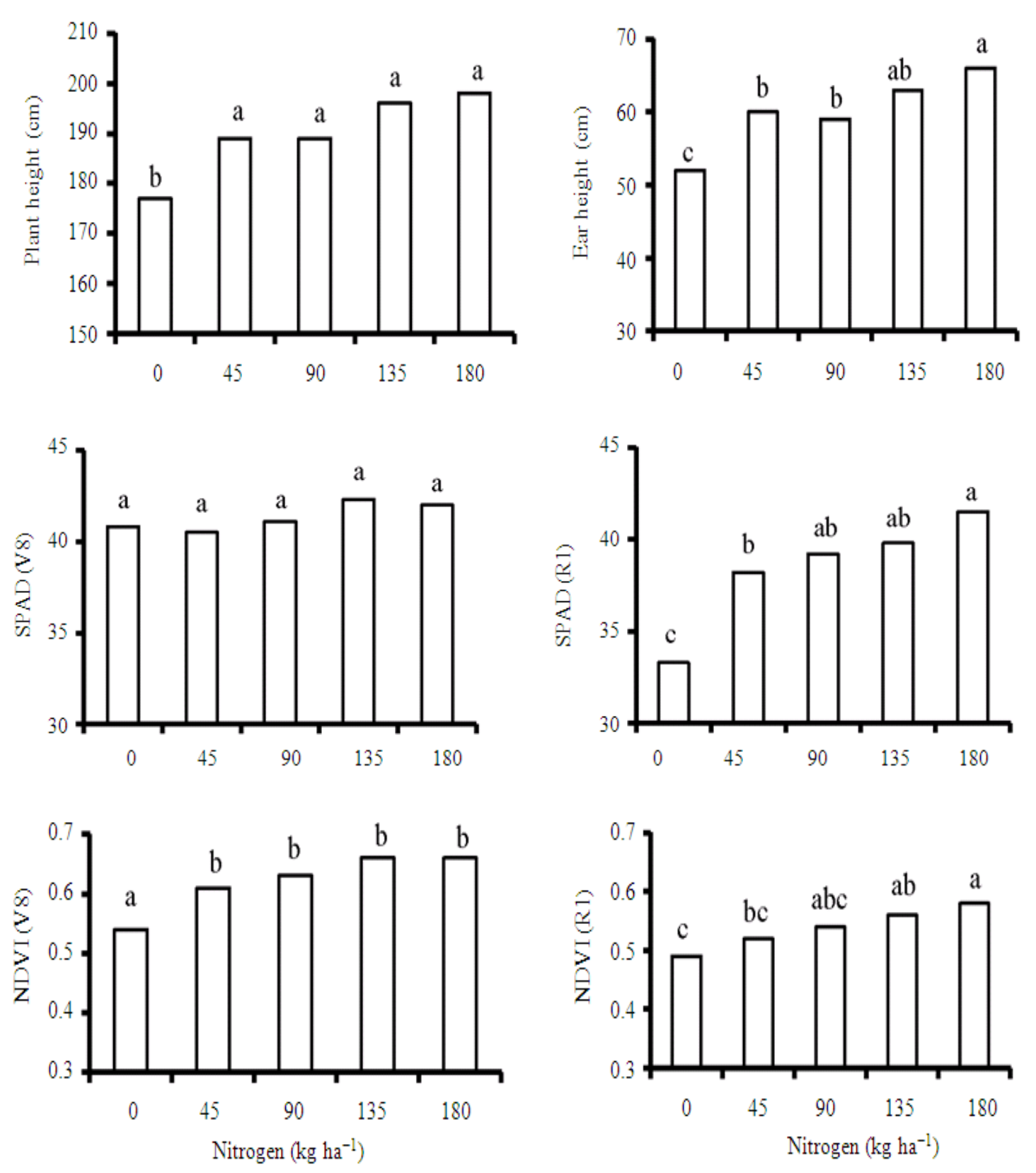

Fig. 1: The influence of $\mathrm{N}$ rate on plant height and ear height at R1 growth stage, SPAD at V8 and R1 stages and NDVI at V8 and R1 stages. The bars followed by different letters indicate significant difference $(p \leq 0.05)$

Table 2: Correlations between corn grain yield, plant and ear height and SPAD and NDVI at V8 and R1 growth stages

\begin{tabular}{|c|c|c|c|c|c|c|c|}
\hline & Yield & Plant height & Cob height & SPAD (V8) & SPAD (R1) & NDVI (V8) & NDVI (R1) \\
\hline \multicolumn{8}{|l|}{ Grain yield } \\
\hline Plant height & 0.051 & & & & & & \\
\hline Ear height & $0.281^{*}$ & $0.915 *$ & & & & & \\
\hline SPAD (V8) & 0.138 & $0.612 *$ & $0.494 *$ & & & & \\
\hline SPAD (R1) & 0.110 & $0.562 *$ & $0.517 *$ & -0.088 & & & \\
\hline NDVI (V8) & $0.410^{*}$ & $0.844^{*}$ & $0.845^{*}$ & $0.512 *$ & $0.376^{*}$ & & \\
\hline NDVI (R1) & $0.236^{*}$ & $0.781 *$ & $0.761^{*}$ & $0.381 *$ & $0.637^{*}$ & $0.778 *$ & \\
\hline
\end{tabular}




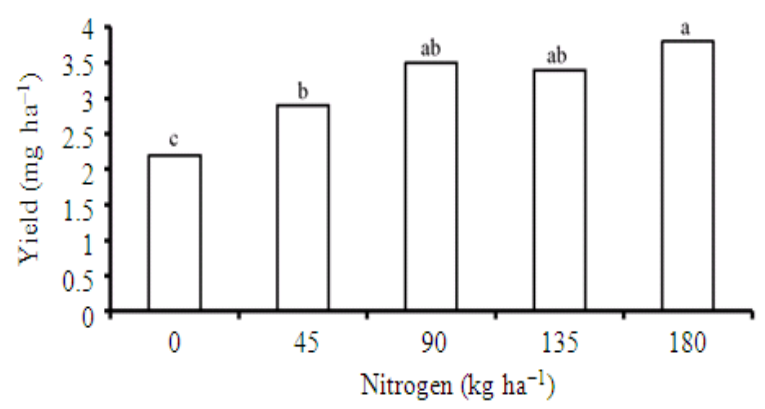

Fig. 2: The influence of $\mathrm{N}$ fertilization on corn grain yield. The bars followed by different letters indicate significant difference $(\mathrm{p} \leq 0.05)$
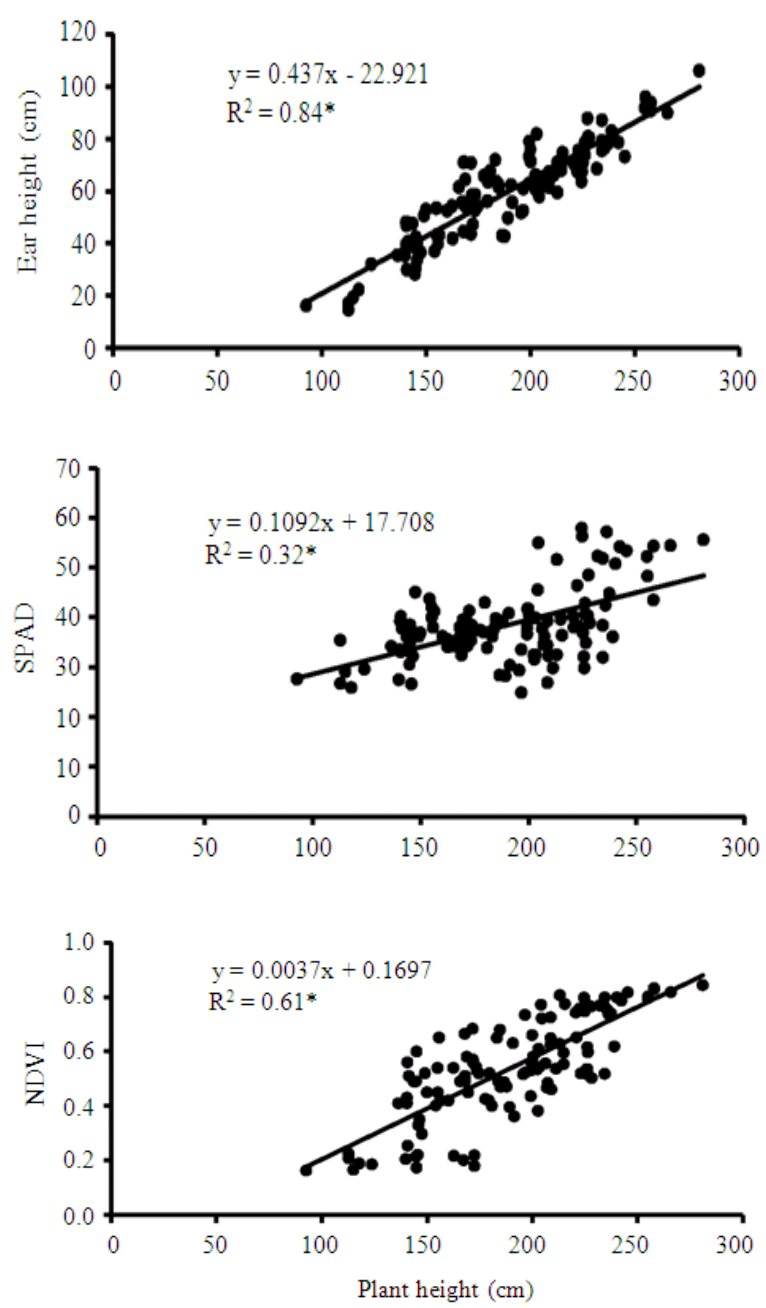

Fig. 3: The relationship between plant height with ear height, SPAD and NDVI measured at R1 growth stage. $*$ indicates significance at $\mathrm{p} \leq 0.05$
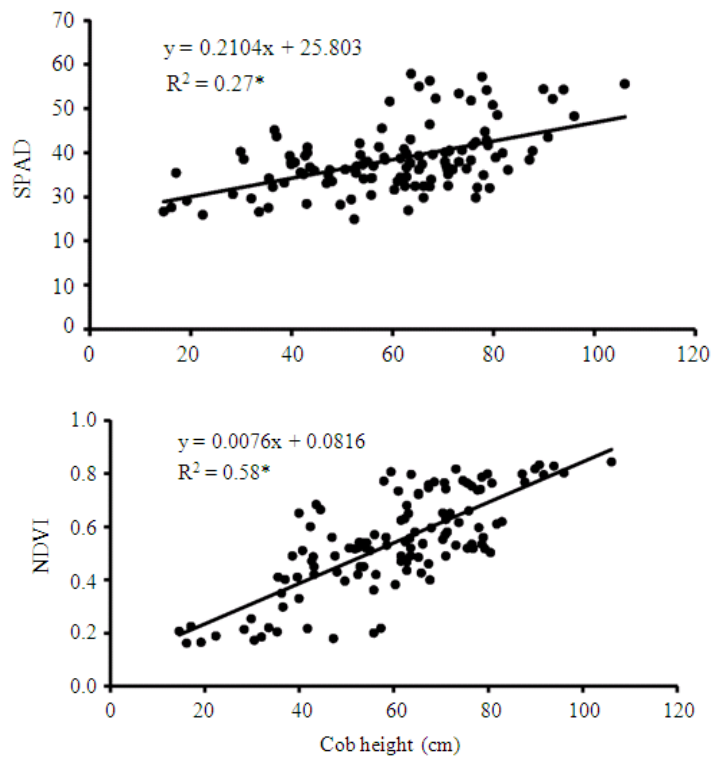

Fig. 4: The relationship between ear height and SPAD and NDVI measured at R1 growth stage. * indicates significance at $\mathrm{p} \leq 0.05$
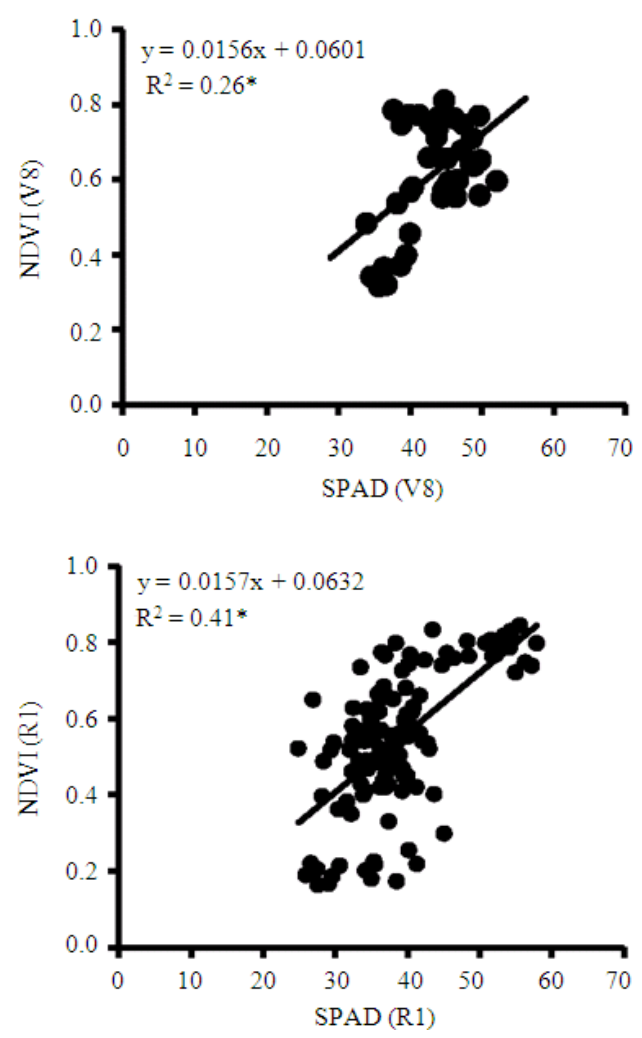

Fig. 5: The relationship between SPAD and NDVI at corn V8 and R1 growth stage. * indicates significance at $\mathrm{P} \leq 0.05$ 


\section{DISCUSSION}

$\mathrm{N}$ availability has been shown to play an important role in corn plant growth and elongation (Rui et al., 2009). Bukan et al. (2009) reported that with $150 \mathrm{~kg} \mathrm{~N}$ $\mathrm{ha}^{-1}$ applied to corn, significantly increased grain yield by $9.09 \%$, ear height by $4.13 \%$ and leaf length and width by 2.36 and $4.30 \%$, respectively, compared to treatments without $\mathrm{N}$ application. In our study, plant and ear height at R1 growth stage increased by 12 and $27 \%$, respectively, with increased $\mathrm{N}$ application from 0 $180 \mathrm{~kg} \mathrm{~N} \mathrm{ha}^{-1}$. SPAD at V8 growth stage did not differ among $\mathrm{N}$ rates and the increase of NDVI with $\mathrm{N}$ rate was only up to $45 \mathrm{~kg} \mathrm{~N} \mathrm{ha}^{-1}$. It was probably due to the low uptake of $\mathrm{N}$ by corn by the V8 growth stage. At R1 stage, SPAD and NDVI showed relatively higher value compared to treatment without $\mathrm{N}$ application. This was probably related to the increase of $\mathrm{N}$ uptake and then resulted in the increase in corn leaf greenness and canopy light absorption. Janos (2010) reported a close correlation between $\mathrm{N}$ fertilization and SPAD readings. Increasing $\mathrm{N}$ application increased $\mathrm{N}$ content and chlorophyll content in corn (Pandey et al., 2000; Rambo et al., 2010). Clay et al. (2006) observed that increasing the $\mathrm{N}$ rate from $0-112 \mathrm{~kg} \mathrm{~N} \mathrm{ha}^{-1}$ decreased reflectance in the red $(661 \mathrm{~nm})$ bands at V8-V9 corn growth stage. Nitrogen stress reduced the production of chlorophyll that is involved in the photosynthesis. Reduced chlorophyll content increased reflectance of photosynthetically active light (Rui et al., 2009) and contributed to low SPAD and NDVI readings from treatments without $\mathrm{N}$ application.

Corn grain yield varied among years most likely due to insufficient rainfall during corn critical stages. In June, during corn reproductive stages, rainfall was very low in 2008 and 2009 compared with 2007, 44 and 54 $\mathrm{mm}$ vs. $151 \mathrm{~mm}$ (Table 1). Insufficient water availability during the corn reproductive silking stage, which is the most critical stage, most likely contributed to reduced yields. Haghighi et al. (2010) and Viswakumar et al. (2008) reported very poor corn yields under dry conditions due to insufficient rainfall and little response to $\mathrm{N}$ application. Kiziloglu et al. (2009) observed a linear relationship between water use efficiency and corn grain yield. They found that higher water deficiency resulted in a significant reduction in water use efficiency and corn yields.

Increasing $\mathrm{N}$ fertilization increased corn grain yield. It was consistent with other studies (Halvorson et al., 2005; Gagnon and Ziadi, 2010). Halvorson et al. (2005) reported a significant increase in grain yields with rates up to $224 \mathrm{~kg} \mathrm{~N} \mathrm{ha}{ }^{-1}$ under irrigated conditions. Ma et al. (2005) observed that corn grain yields increased significantly with rates up to $120 \mathrm{~kg} \mathrm{~N}$ $\mathrm{ha}^{-1}$. Al-Kaisi and Kwaw-Mensah (2007) reported in their study that $\mathrm{N}$ rate of $85 \mathrm{~kg} \mathrm{ha}^{-1}$ increased corn grain yield. In our study, grain yields increased with the $\mathrm{N}$ application of up to $90 \mathrm{~kg} \mathrm{ha}^{-1}$. Further increase in $\mathrm{N}$ application did not result in significant yield increase. Water availability and insufficient rainfall was most likely limiting factor to $\mathrm{N}$ use efficiency. Fertilization timing did not influence corn grain yield. Other studies also showed a lack of effect of $\mathrm{N}$ application timing on corn grain yields (Tarkalson et al., 2009). However, Gehl et al. (2005) observed that corn N uptake improved and grain yield increased with split $\mathrm{N}$ fertilization compared to one single application at planting under irrigation system. The yield increase observed in these studies with the split $\mathrm{N}$ application was due to sufficient water availability and improved $\mathrm{N}$ utilization. Ma et al. (2005) observed that drought conditions may severely affect $\mathrm{N}$ utilization and corn yields. In our study, irregular distribution of rainfall was most likely a factor affecting $\mathrm{N}$ utilization.

The research results are not consistent about the relationship between corn plant characteristics and grain yield. Some studies reported no association between corn grain yield and SPAD (Bullock and Anderson, 1998) and NDVI (Teal et al., 2006) at growth stages between V6 and V9 stages, but other research has shown a strong relationship between these parameters and corn grain yield at around V8 to R1 growth stage (Vetsch and Randall, 2004; Inman et al., 2007). A study by Machado et al. (2002) showed that $61 \%$ of the variation in grain yield could be explained by plant height in a dry year. In our study, plant NDVI and ear height were significantly correlated with grain yields; however, no significant correlation was observed for plant height and SPAD with grain yields. It indicates that NDVI at V8 and R1 growth stage may act as a good predictor to estimate corn grain yield. They reported that plant NDVI was strongly correlated with SPAD at almost all growth stages. This indicates that one of these canopy variables may be a good predictor of another plant characteristic.

\section{CONCLUSION}

Plant height, ear height, SPAD and NDVI at V8 and R1 generally increased with increasing $\mathrm{N}$ rates; however, single or split $\mathrm{N}$ application did not have a significant effect on corn yields or plant characteristics. Corn grain yield increased with increasing $\mathrm{N}$ rate up to $90 \mathrm{~kg} \mathrm{~N} \mathrm{ha}^{-1}$, after that no significant yield increase was observed. Grain yield was significantly correlated with 
ear height at R1 corn stage and plant NDVI at V8 and R1 stages. Plant height, ear height, SPAD and NDVI showed a significant positive linear correlation among each other at V8 or R1 stage. Overall, applying more than $90 \mathrm{~kg} \mathrm{~N} \mathrm{ha}^{-1}$ did not significantly increase grain yields and plant NDVI may be a good indicator in evaluating the yield potential of dryland corn under low yield environment.

\section{ACKNOWLEDGEMENT}

We appreciate the support from International Plant Nutrition Institute (IPNI). This material is also based upon work supported by NIFA/USDA, under project number SC-1700328. Technical Contribution No. 5889 of the Clemson University Experiment Station.

\section{REFERENCES}

Al-Kaisi, M. and D. Kwaw-Mensah, 2007. Effect of tillage and nitrogen rate on corn yield and nitrogen and phosphorus uptake in a corn-soybean rotation. Agron. J., 99: 1548-1558.

Bukan, M., H. Sarcevic, J. Gunjaca, S. Bolaric and V. Kozumplik, 2009. Response of S1 maize progeny to nitrogen deficiency stress in a recurrent selection program. Cereal Res. Commu., 37: 37-40.

Bullock, D.G. and D.S. Anderson, 1998. Evaluation of the Minolta SPAD-502 chlorophyll meter for nitrogen management in corn. J. Plant Nutri., 21: 741-755. DOI: $10.1080 / 01904169809365439$

Clay, D.E., K.I. Kim, J. Chang, S.A. Clay and K. Dalsted, 2006. Characterizing water and nitrogen stress in corn using remote sensing. Agron. J., 98: 579-587. DOI: 10.2134/agronj2005.0204.

Endale, D.M., H.H. Schomberg, D.S. Fisher, M.B. Jenkins and R.R. Sharpe et al., 2008. No-till corn productivity in a southeastern United States ultisol amended with poultry litter. Agron. J., 100: 1401-1408. DOI: 10.2134/agronj2007.0401

Fabrizzi, K.P., F.O. Garcia, J.L. Costa and L.I. Picone, 2005. Soil water dynamics, physical properties and corn and wheat responses to minimum and notillage systems in the southern Pampas of Argentina. Soil Tillage Res., 81: 57-69. DOI: 10.1016/j.still.2004.05.001

Fawcett, R. and D. Towery, 2002. Conservation Tillage and Plant Biotechnology: How New Technologies can Improve the Environment by Reducing the Need to Plow. Conservation Technology Information Center. http://www.whybiotech.com/resources/tps/Conserv ationTillageandPlantBiotechnology.pdf
Freeman, K.W., K. Girma, D.B. Arnall, R.W. Mullen and K.L. Martin et al., 2007. By-plant prediction of corn forage biomass and nitrogen uptake at various growth stages using remote sensing and plant height. Agron. J., 99: 530-536. DOI: 10.2134/agronj2006.0135

Freund, R.J. and R.C. Littell, 2000. SAS System for Regression. 3rd Edn., SAS Publishing, USA., ISBN-10: 9781580257251, pp: 236.

Gagnon, B. and N. Ziadi, 2010. Grain corn and soil nitrogen responses to sidedress nitrogen sources and applications. Agron. J., 102: 1014-1022. DOI: 10.2134/agronj2010.0011

Gehl, R.J., J.P. Schmidt, L.D. Maddux and W.B. Gordon, 2005. Corn yield response to nitrogen rate and timing in sandy irrigated soils. Agron. J., 97: 1230-1238. DOI: 10.2134/agronj2004.0303

Haghighi, B.J., Z. Yarmahmodi, and O. Alizadeh, 2010. Evaluation the effects of biological fertilizer on physiological characteristic and yield and its components of corn (Zea mays L.) under drought stress. Am. J. Agric. Biol. Sci., 5: 189-193. DOI: 10.3844/ajabssp.2010.189.193

Halvorson, A.D., A.R. Mosier, C.A. Reule and W.C. Bausch, 2005. Nitrogen and tillage effects on irrigated continuous corn yields. Agron. J., 98: 63-71. DOI: 10.2134/agronj2005.0174

Inman, D., R. Khosla, R.M. Reich and D.G. Westfall, 2007. Active remote sensing and grain yield in irrigated maize. Precision Agric., 8: 241-252. DOI: 10.1007/s11119-007-9043-z

Inman, D., R. Khosla, R.M. Reich and D.G. Westfall, 2008. Normalized difference vegetation index and soil color-based management zones in irrigated maize. Agron. J., 100: 60-66.

Janos, N., 2010. Impact of fertilization and irrigation on the correlation between the soil plant analysis development value and yield of maize. Commun. Soil Sci. Plant Anal., 41: 1293-1305. DOI: 10.1080/00103621003759304

Kiziloglu, F.M., U. Sahin, Y. Kuslu and T. Tunc, 2009. Determining water-yield relationship, water use efficiency, crop and pan coefficients for silage maize in a semiarid region. Irri. Sci., 27: 129-137. DOI: 10.1007/s00271-008-0127-y

Littell, R.C., G.A. Milliken, W.W. Stroup, R.D. Wolfinger and O. Schabenberger, 2006. SAS for Mixed Models. 2nd Edn., SAS Institute Inc., USA., ISBN-10: 9781590475003 , pp: 840.

Ma, B.L., K.D. Subedi and C. Costa, 2005. Comparison of crop-based indicators with soil nitrate test for corn nitrogen requirement. Agron. J., 97: 462-471. DOI: 10.2134 /agronj2005.0462 
Machado, S., E.D. Bynum, T.L. Archer, R.J. Lascano and L.T. Wilson et al., 2002. Spatial and temporal variability of corn growth and grain yield. Crop Sci., 42: 1564-1576. $\quad$ DOI: 10.2135/cropsci2002.1564

Martin, K.L., K. Girma, K.W. Freeman, R.K. Teal and B. Tubana et al., 2005. Expression of variability in corn as influenced by growth stage using optical sensor measurements. Agron. J., 99: 384-389. DOI: 10.2134/agronj2005.0268

Pandey, R.K., J.W. Maranville and M.M. Chetima, 2000. Deficit irrigation and nitrogen effects on maize in a Sahelian environment: II. Shoot growth, nitrogen uptake and water extraction. Agric. Water Manage., 46: 15-27. DOI: 10.1016/s03783774(00)00074-3

Raczkowski, C.W., M.R. Reyes, G.B. Reddy, W.J. Busscher and P.J. Bauer, 2009. Comparison of conventional and no-tillage corn and soybean production on runoff and erosion in the southeastern US Piedmont. J. Soil and Water Conser., 64: 53-60. DOI: 10.2489/Jswc.64.1.53

Rambo, L., B.L. Ma, Y. Xiong and P.R.F. da Silvia, 2010. Leaf and canopy optical characteristics as crop-N-status indicators for field nitrogen management in corn. J. Plant Nutr. Soil Sci., 173: 434-443. DOI: 10.1002/jpln.200900022

Raun, W.R., J.B. Solie, K.L. Martin, K.W. Freeman and M.L. Stone et al., 2005. Growth stage, development, and spatial variability in corn evaluated using optical sensor readings. J. Plant Nutr., 28: 173-182. DOI: 10.1081/Pln-200042277

Rui, Y.K., Y.F. Peng, Z.R. Wang and J.B. Shen, 2009. Stem perimeter, height and biomass of maize (Zea mays L.) grown under different $\mathrm{N}$ fertilization regimes in Beijing, China. Inter. J. Plant Pro., 3: 85-90.
SAS Institute, Inc., 2000. SAS/STATT ${ }^{\circledR}$ User's Guide, Version 8. 1st Edn., SAS Publishing, USA., ISBN10: 1580254942, pp: 3809.

Shanahan, J.F., J.S. Schepers, D.D. Francis, G.E. Varvel and W.W. Wilhelm et al., 2001. Use of remote-sensing imagery to estimate corn grain yield. Agron. J., 93: 583-589. DOI:10.2134/agronj2001.933583x

Spargo, J.T., M.M. Alley, R.F. Follett and J.V. Wallace, 2008. Soil carbon sequestration with continuous no-till management of grain cropping systems in the Virginia coastal plain. Soil Tillage Res., 100: 133-140. DOI: 10.1016/j.still.2008.05.010

Tarkalson, D.D., S.J. Van Donk and J.L. Petersen, 2009. Effect of nitrogen application timing on corn production using subsurface drip irrigation. Soil Sci., 174 : $174-179 . \quad$ DOI: 10.1097/Ssl.0b013e3181998514

Teal, R.K., B. Tubana, K. Girma, K.W. Freeman and D.B. Arnall et al., 2006. In-season prediction of corn grain yield potential using normalized difference vegetation index. Agron. J., 98: 1488-1494. DOI: 10.2134/agronj2006.0103

Uribelarrea, M., S.J. Crafts-Brandner and F.E. Below, 2009. Physiological $\mathrm{N}$ response of field-grown maize hybrids (Zea mays L.) with divergent yield potential and grain protein concentration. Plant Soil, 316: 151-160. DOI: 10.1007/s11104-0089767-1

Vetsch, J.A. and G.W. Randall, 2004. Corn production as affected by nitrogen application timing and tillage. Agron. J., 96: 502-509. DOI: 10.2134/agronj2004.5020

Viswakumar, A., R.W. Mullen, A. Sundermeier and C.E. Dygert, 2008. Tillage and nitrogen application methodology impacts on corn grain yield. J. Plant Nutr., $\quad 31$ : 1963-1974. $\quad$ DOI: $10.1080 / 01904160802403102$ 